\title{
Elevated Glucocorticoid Receptor Concentrations before and after Glucocorticoid Therapy in Peripheral Mononuclear Leukocytes of Patients with Atopic Dermatitis
}

\author{
M. Rupprecht, R. Rupprecht, J. Kornhuber, N. Wodarz, H.U. Koch, P. Riederer, O.P. Hornstein \\ Department of Dermatology, University of Erlangen-Nürnberg; Department of Psychiatry, University of Würzburg; \\ Max Planck Institute of Psychiatry, München, FRG
}

Key Words. Glucocorticoids · Glucocorticoid receptors · Atopic dermatitis

\begin{abstract}
The number and affinity of glucocorticoid binding sites in peripheral mononuclear leukocytes of patients with atopic dermatitis (AD) and healthy controls were determined under baseline conditions and after a defined oral glucocorticoid treatment. Patients with $\mathrm{AD}(\mathrm{n}=15)$ exhibited significantly more glucocorticoid receptors $(\mathrm{GR})$ per cell than the control group $(n=22)$, while the GR affinity did not differ. Methylprednisolone treatment resulted in a significant reduction of the GR sites per cell in the steroid-treated control group $(n=10)$ in contrast to the patients. The dissociation constant was not affected by methylprednisolone treatment in either group. In view of the therapeutic efficiency of glucocorticoids in AD and findings of abnormal cAMP and cAMP-phosphodiesterase activity, the elevated GR concentrations in AD lend support to the hypothesis of a compensatory GR upregulation due to an insufficient action of endogenous cortisol or to altered cAMP-induced GR expression.
\end{abstract}

\section{Introduction}

Studies on patients with atopic dermatitis (AD) have revealed a variety of immunological, hormonal and psychological [1,2] derangements including elevations of IgE levels [3, 4], disordered cell-mediated immunity [5-7], abnormal cAMP and cAMP-phosphodiesterase activity $[8,9]$ and an impairment of $\beta$-adrenoceptor function $[10$, 11]. Recent investigations pointed to a possible hormonal dysregulation of the hypothalamic-pituitary-adrenal (HPA) system in AD. Slightly lowered baseline values of cortisol [12] in face of a normal adrenomedullar function [13], minor imbalances in the circadian rhythm of cortisol serum levels [14] as well as a reduced urine excretion rate of steroid metabolites contrasting with normal cortisol blood levels [15] have been noted.

Topical and systemic administration of glucocorticoids is of major importance in the treatment of AD. The effects of glucocorticoids are mainly mediated via specific intracellular receptors which have been identified in various mammalian and human tissues, e.g. the skin [16-18], lung [19], brain [20] and mononuclear leukocytes [21-23].

As the glucocorticoid receptor (GR) has been shown to underlie an autoregulatory control in skin fibroblasts $[17,18]$ and in human leukocytes [21-26], the present study was designed to explore the potential role of GR autoregulation for the alteration of the HPA system in AD.

\section{Material and Methods}

\section{Subjects}

Fifteen inpatients ( 3 men and 12 women) suffering from AD and 22 healthy controls ( 11 men, 11 women) without personal history of asthma, hay fever or AD participated in the study voluntarily with informed consent. The patients were aged between 18 and 36 years (mean \pm SD: $23.4 \pm 5.6)$ and the controls for baseline studies between 19 and 42 years (mean \pm SD: $28.5 \pm 6.3$ ). Ten of the healthy subjects ( 4 men, 6 women; 
mean age \pm SD: $24.3 \pm 2.8$ years), who had the same age as the patients. agreed to further participate in the study and received the same steroid dosage as the patients for the autoregulation study.

All participants were withdrawn from any systemic therapy with corticoids or adrenocorticotropic hormone at least 2 months prior to the study. Medication, if any, with $\beta$-blocking and/or sleep-inducing drugs was stopped 3 or more days before entering the study. Cutancous lesions of $\mathrm{AD}$ were treated only with corticoid-free ointments at leas 1 week before onset and during the study.

Exclusion criteria were prevalence of severe internal illness and alcohol, drug or nicotine abuse. Seven of the patients and tof the 10 healthy controls were taking birth control pills.

The diagnosis of $\mathrm{AD}$ was based on the history of recurrent flexural eczema, personal and/or family history of atopy and clinical criteria of $\mathrm{AD}$ as established by Hanifin and Rajka [27]. The severity of cutalleous involvement was evaluated according to Costa et al. [28] and reveakd moderate to marked disease activity. The score ranged between .37 and 69 points (mean \pm SD: $47.6 \pm 10.6$ ) before therapy and between 11 and 55 points (mean \pm SD: $27.9 \pm 10.7$ ) at the end of the study. None of the patients suffered from actual bronchial asthma.

\section{Study Design}

After obtaining the baseline GR and hormone parameters. all patients and the steroid-treated controls underwent a l-mg dexamethasone suppression test (DST) and subsequent oral methylprednisolone therapy as shown in table 1 . The DST was used to evaluate the integrity of the feedback regulation of the HPA system.

For determination of GR binding characteristics and hormone dati peripheral venous blood samples were collected into EDTA-containing plastic tubes (Sarstedt, FRG).

\section{Cell Preparation and Binding Assay}

Mononuclear cell fraction was prepared by sodium metrizoateFicoll (Sigma, St. Louis, Mo., USA) density gradient centrifugation [29]. Cells were washed twice in phosphate-buffered saline (PBS. pH 7.4; Boehringer, Mannheim, FRG) for $10 \mathrm{~min}$, incubated for $60 \mathrm{~min}$ at $37^{\circ} \mathrm{C}$ in PBS and then washed again to allow sufficient dissociation of endogenous hormone. The final concentration of cells was determined using a Coulter counter (Model S5, Coulter Electronics Ltd. UK). Viability of cells exceeded $95 \%$, as judged from their ability to exclude trypan blue. Contamination by erythrocytes was $<10 \%$, hy granulocytes and monocytes $<8 \%$.

Binding experiments as described by Rupprecht et al. $[25]$ were carried out at $37^{\circ} \mathrm{C}$ in plastic microtiter plates in a total volume of 0.25 $\mathrm{ml}$. The displacing compound in a final concentration of $10 \mu \mathrm{M}$ unlabeled dexamethasone (Sigma, St. Louis, Mo. . USA) solved in .5\% cthanol, containing $5 \mathrm{~m} M D$-glucose, was added to half of the samples to determine nonspecific binding immediately prior to the addition of $\left[{ }^{3} \mathrm{H}\right]$ dexamethasone (Amersham, UK). Increasing concentrations of $\left[{ }^{3} \mathrm{H}\right]$ dexamethasone (specific activity: $84 \mathrm{Ci} / \mathrm{mmol}$ ) from 1 to $40 \mathrm{nM}$ were used. Saturation experiments were carried out at equilibrium after $90 \mathrm{~min}$ incubation in PBS with $5 \mathrm{mM} \mathrm{D}$-glucose at $37^{\circ} \mathrm{C}$. After incubation, bound ligand was separated from frec ligand hy rapid filtration through Scatron filters (No. 11731) with a Titertek cell harvester by two 5 -second washes with PBS at room temperature. The filters were transferred into plastic vials, $5 \mathrm{ml}$ of a toluene-hased scintillation cocktail was added (Rotiszint 22: Roth. Karlsruhe. FR(i) and they were monitored for tritium in a Beckman LS 1801 counter at about $54 \%$ efficiency. All samples were assayed in triplicate with a variation coefficient $<7 \%$.

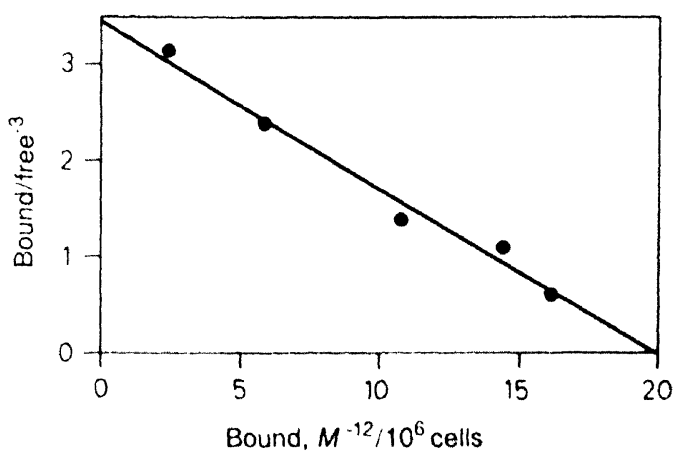

Fig. 1. Scatchard plet of |'llkkexamethasone binding to human monomuclear leukocyes. Specifically bound/free ['H/dexamethasone is ploted versus specifically bound / II/kexamethasone.

Table 1. Study design

\begin{tabular}{|c|c|c|}
\hline Dats & Time & Gilucocorticoid dones) \\
\hline \multirow[t]{3}{*}{1} & $7 \mathrm{a} . \mathrm{m}$. & \\
\hline & $4 p . m$. & \\
\hline & $11 \mathrm{p} . \mathrm{m}$. & I mgdexamethasene \\
\hline 2 & $7 \mathrm{ar.m}$ & \\
\hline & tp.m. & \\
\hline $3-6$ & $7 a . m$ & smg methylprednisolone \\
\hline $7-1$ & $7: 1 . m$. & $4 \mathrm{mg}$ methylprednisolonc \\
\hline 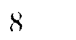 & tp.m. & \\
\hline
\end{tabular}

Bloodsamples

hormone datit

hormone + receptor data

hormone datis

hormone data

hormone + receptordata

Table 2. (ortisol mein $+\mathrm{SI})$ values $(\mu \mathrm{g} / \mathrm{d} l)$ inpaticnts $(n=15)$ and controls $(n-10)$

\begin{tabular}{|c|c|c|c|c|c|}
\hline & $A$ & & B & & (') \\
\hline & $7 a \mathrm{~m}$ & $4 p . m$. & $7 \mathrm{il.m}$ & $4 p . m$. & $4 p . m$. \\
\hline ationts & $27.5+1.3 .8$ & $1.3 .4+11 . .^{3}$ & $1.6+1.4$ & $4.1+4.0$ & 6 \\
\hline Controks & $25.1+8.6$ & $14.6+0.9$ & $2.3+1.5$ & $3.3+3.3$ & $7.7+5$ \\
\hline
\end{tabular}

A Bancline levels: $B$ affer oral administration of $1 \mathrm{mg}$ dexatmethasone: (c-after oral methylprednisolone treatment

Table 3. (iR sites in female patients and female controk taking and not taking hirth control pills under bascline conditions and after methy. prednisolone treatment

$\begin{array}{lll} & \text { Pill } & \text { Nopill } \\ \text { Patients } & n=7 & n=5 \\ \text { Baseline } & 3.78 .3+1.658 & 3.5860+1.5 .37 \\ \text { Prednisolone } & 3.353+1.1015 & 3.250+1.64 . \\ \text { Controls } & n-4 & n=2 \\ \text { Bascline } & 2.642+567 & 2.764+859 \\ \text { Prednisolone } & 2.03(1+470 & 2.087+14\end{array}$




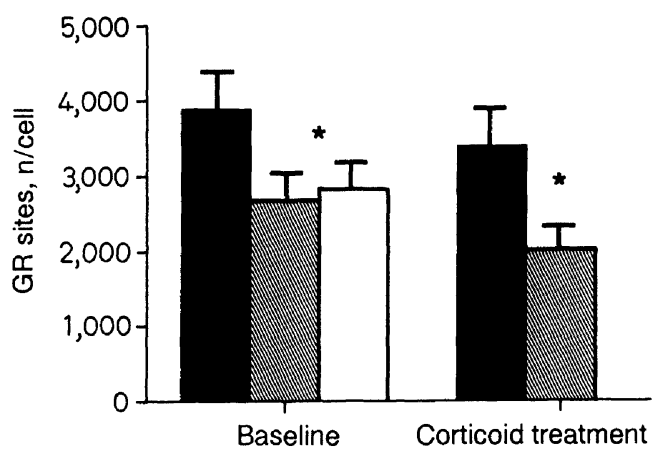

Fig. 2. GR sites per cell. Means $\pm S E$, in patients with $A D(\boldsymbol{\square}$, $n=15)$, the corticoid-treated controls $(\mathbb{N}, n=10)$ and the whole control group $(\square, n=22)$ before (baseline) and after glucocorticoid treatment. The asterisks indicate significant differences $(p<0.02)$.

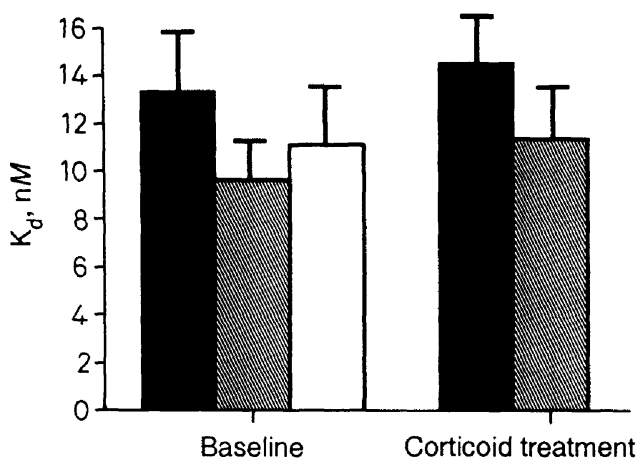

Fig. 3. $K_{d}$. Means $\pm S E$, in patients with $\operatorname{AD}(\boldsymbol{a}, n=15)$, the corticoid-treated controls $(\mathbb{N}, n=10)$ and the whole control group $(\square$, $\mathrm{n}=22$ ) before (baseline) and after glucocorticoid treatment.

Receptor levels and the dissociation constant $\left(\mathrm{K}_{\mathrm{d}}\right)$ were determined by Scatchard plots [30]. A typical Scatchard plot of $\left[{ }^{3} \mathrm{H}\right]$ dexamethasone is shown in figure 1.

Specific binding was determined by subtracting the nonspecific from total binding. Nonspecific binding (in percent of total binding) at a concentration of $10 \mathrm{nM}\left[{ }^{3} \mathrm{H}\right]$ dexamethasone was $28 \pm 18 \%$ in patients and $26 \pm 15 \%$ in controls.

\section{Cortisol Assay}

Cortisol was measured by an enzyme-linked immunoassay (Elias, Freiburg, FRG). The lower detection limit was $22 \mathrm{nmol} / \mathrm{l}$, and the intraand interassay coefficients of variation were $6 \%$ for both.

Cortisol nonsuppression was defined as the inability to suppress both postdexamethasone cortisol levels to below $5 \mu \mathrm{g} / \mathrm{dl}$ [31].
Statistical Analysis

Preliminary estimates of binding parameters from saturation experiments were provided by the EBDA program. Final estimates of binding parameters were determined with a computerized nonlinear, least-square regression analysis [32]. This weighted curve fitting program assumes binding according to the law of mass action to independent classes of binding sites. The results are expressed as the mean $\pm \mathrm{SD}$, and as the mean $\pm \mathrm{SE}$ in the figures.

Data were analyzed using the t-test for paired or group samples and Pearson's product moment correlation. All significance levels are twotailed.

\section{Results}

Cortisol mean values of the patients and the controls did not differ significantly at any of the blood sampling time points during the 1-mg DST (table 2). Three of the patients and 2 of the controls fulfilled the criterion for cortisol nonsuppression.

Comparison of the postmethylprednisolone cortisol levels to the 4 p.m. baseline levels revealed significant reduction in patients and controls $(\mathrm{p}<0.03)$.

The patients had significantly $(\mathrm{p}<0.02)$ more GR sites per cell than controls (fig. 2). After methylprednisolone therapy the patients revealed a slightly smaller mean number of GR sites per cell in relation to the baseline values (mean baseline: 3,894 $\pm 1,521$; after treatment: $3,394 \pm 1,189$, not significant), whereas in the controls $(n=10)$ a significant reduction of the GR sites was found (mean baseline: $2,695 \pm 582$; after treatment: $2,036 \pm 410$, $\mathrm{p}<0.02$ ).

The significantly more GR binding sites per cell persisted after therapy in the patient group when compared with the steroid-treated control group $(p<0.002)$.

There was no difference in baseline or methylprednisolone-treated GR sites between female subjects taking birth control pills and those who did not (table 3 ).

The $\mathrm{K}_{\mathrm{d}}$ did not differ at baseline condition and after methylprednisolone treatment in both groups (fig. 3). No relations were found between age, sex, cortisol levels, severity of the skin disorder and GR binding parameters under the conditions studied.

\section{Discussion}

Although slightly lowered baseline cortisol serum concentrations in patients with AD have been observed [12], our study is in accordance with reports on normal cortisol levels in $\mathrm{AD}$ [15]. Twenty percent of the patients with $\mathrm{AD}$ and $20 \%$ of the controls showed no suppression of cortisol 
to below $5 \mu \mathrm{g} / \mathrm{dl}$ after $1 \mathrm{mg}$ dexamethasone. However, abnormal DST data may not only occur in various diseases but can also be induced by multiple interference factors such as stress and weight loss in healthy subjects [33, 34]. Therefore, the abnormal DST results obtained in AD and healthy controls may represent an unspecific finding.

As no data are available on GR binding characteristics in AD we used peripheral blood mononuclear leukocytes to study GR pharmacology, partly for their easy accessibility but also for their relevance to the pathogenesis in $\mathrm{AD}[35]$ as emphasized by the finding that bone marrow transplantation for other reasons could either confer the state of atopy to former nonatopics [36, 37] or may clear $\mathrm{AD}$ in patients with a concomitant immune deficiency disorder [38].

The elevated GR concentrations found in the patients with AD are probably not representing a causal factor, otherwise worsening of the skin lesions would be expected at the beginning of glucocorticoid treatment due to an increased number of activated hormone-receptor complexes. An upregulation of the glucocorticoid binding sites as a compensatory mechanism is more likely. Possible hypotheses for such an upregulation may be alterations in cAMP-induced GR expression [39], activation of the GR synthesis by unspecific mediators [40] or a relative biological inefficiency of endogenous corticoids. The latter hypothesis might be supported by the well-known benefit of glucocorticoids for the treatment of AD and also by the frequent occurrence of a rebound phenomenon after discontinuation of glucocorticoid administration. An increase in receptor protein half-life $[39,41]$ due to reduced cortisol-receptor interactions as supposed after depletion of endogenous cortisol following metyrapone administration [26] or adrenalectomy [42], or an enhanced transcription rate for the GR [43] may also be responsible for the elevated GR sites in AD.

No correlations were found between endogenous cortisol levels and GR binding sites in the control and patient group. This result is in accordance with previous studies in healthy and asthmatic subjects $[26,44,45]$ and indicates that the plasma concentrations of endogenous glucocorticoids at the time of the GR assay are of minor importance for the estimation of GR number.

However, prolonged glucocorticoid administration results in downregulation of the number of GR $[18,21$, 24] by influencing GR gene transcription [46] without significantly affecting the binding affinity. In the controls methylprednisolone administration was followed by a significant decrease in GR binding, whereas in the patients with $\mathrm{AD}$ only a slight reduction of GR binding was observed. This finding might be interpreted as a diminished downregulation of GR by exogenous glucocorticoids which could be due to the heterogeneity of the patient group shown by the greater standard deviation and might also be compatible with the hypothesis of a cAMP-induced overdrive of GR expression [39] or a relative biological inefficiency of endogenous cortisol which would require a greater amount of exogenous glucocorticoids to downregulate the GR. However, it cannot be excluded that an eventual displacement of receptorbound methylprednisolone by dexamethasone during the assay may underlie different kinetics in patients with AD which might affect the estimation of $K_{d}$ and $B_{\max }$ values. The use of monoclonal antibodies for quantification of GR expression [47] might overcome the difficulties with ligand exchange assays and furnish a direct proof for the hypothesis of a decreased GR downregulation in AD.

As no data are available on GR in other inflammatory skin diseases so far, the specificity of the present findings is still questionable. However, although $\mathrm{AD}$ and bronchial asthma are often closely associated [48] and glucocorticoid therapy is efficient in both diseases [44], normal lymphocyte GR content and affinity has been described in asthmatic subjects $[44,45]$.

In line with observations that patients with $\mathrm{AD}$ exhibit a minor derangement of the HPA system shown by imbalances of the circadian rhythm of cortisol [14] and may have a reduced excretion of glucocorticoids [15], the here reported alterations in GR binding characteristics on mononuclear leukocytes lend further support to the view of AD as being a systemic rather than a mere cutaneous disease.

Future perspectives might be the concomitant analysis of GR behavior in mononuclear leukocytes and cells of both involved and uninvolved skin areas of patients with AD.

\section{Acknowledgements}

We thank Miss Nistelweck for excellent technical assistance. The Johannes and Frieda Marohn Stiftung of the University of ErlangenNürnberg provided financial support.

\section{References}

1 Faulstich ME, Williamson DA, Duchmann EG, Conerly SL, Brantley PP: Psychophysiological analysis of atopic dermatitis. J Psychosom Res 1985;29:415-417.

2 Whitlock FA: Psychophysiologische Aspekte bei Hautkrankheiten: Atopische Dermatitis; in Bosse K, Hünecke P (eds): Beiträge zur Dermatologie. Erlangen, Perimed, 1980, vol 6, pp 141-159. 
3 Wüthrich B: Serum IgE in atopic dermatitis. Clin Allergy 1978; 8:241-248.

4 Juhlin L, Johansson SGO, Bennich H, Högman C, Thyresson N: Immunglobulin $\mathrm{E}$ in dermatoses. Arch Dermatol 1969;100:12-16.

5 Lobitz WC, Honeyman JF, Winkler NW: Suppressed cell-mediated immunity in two adults with atopic dermatitis. Br J Dermatol 1972;86:317-328.

6 Rola-Pleszczynski M, Blanchard R: Abnormal suppressor cell function in atopic dermatitis. J Invest Dermatol 1981;76:279-283.

7 Schöpf E, Kapp A, Kim CW: T-cell function in atopic dermatitis Controlled examination of concanavalin A dose-response relations in cultured lymphocytes. Arch Dermatol Res 1978;262:37-44.

8 Schwarz W, Bock G, Hornstein OP: Plasma levels of cyclic nucleotides are elevated in atopic eczema. Arch Dermatol Res 1987;279: S59-S62.

9 Holden CA, Chan SC, Hanifin JM: Monocyte localization of elevated cyclic AMP phosphodiesterase activity in atopic dermatitis. J Invest Dermatol 1986;87:372-376.

10 Szentivanyi A, Helm O, Schultze P, Szentivanyi J: Adrenoreceptor binding studies with 3-H-(dihydroalprenolol) and 3-H-(dihydroergocryptine) on membranes of lymphocytes from patients with atopic disease. Acta Derm Venereol (Stockh) 1980;92:19-21.

11 Szentivanyi A: The beta adrenergic theory of the atopic abnormality in bronchial asthma. J Allergy 1968;42:203-232.

12 van de Kerkhof PCM: Plasma aldosterone and cortisol levels in psoriasis and atopic dermatitis. Br J Dermatol 1981;106:423-428.

13 Archer CB, Dalton N, Turner C, MacDonald DM: Investigation of adrenomedullary function in atopic dermatitis. $\mathrm{Br} \mathbf{J}$ Dermatol 1987; $116: 793-800$.

14 Heubeck B, Schönberger A, Hornstein OP: Sind Verschiebungen des zirkadianen Cortisolrhythmus ein endokrines Symptom des endogenen Ekzems? Hautarzt 1988;39:12-17.

15 Buhles N, Hölzel C, Spiteller G, Holzmann H, Altmeyer P: Disorders of steroid metabolism in inflammatory dermatoses. Z Hautk 1987;62:1356-1363.

16 Smith K, Shuster S: Characterisation of the glucocorticoid receptor in human epidermis and dermis. Clin Exp Dermatol 1987;12:83-88.

17 Berkovitz GD, Carter KM, Migeon CJ, Brown TR: Downregulation of the glucocorticoid receptor by dexamethasone in cultured human skin fibroblasts: Implications for the regulation of aromatase activity. J Clin Endocrinol Metab 1988;66:1029-1036.

18 Oikarinen A, Oikarinen H, Meeker CA, Tan EML, Uitto J: Glucocorticoid receptors in human skin fibroblasts: Evidence for downregulation of receptor by glucocorticoid hormone. Acta Derm Venereol (Stockh) 1987;67:461-468.

19 Ballard PL, Ballard RA: Cytoplasmic receptors for glucocorticoids in lung of the human fetus and neonate. J Clin Invest 1974;53: 477-486.

20 Fuxe K, Wikström AC, Okret S, Agnati LF, Härfstrand A, Yu ZY, Granhol L, Zoli M, Vale W, Gustafsson JA: Mapping of glucocorticoid receptor immunoreactive neurons in the rat tel- and diencephalon using a monoclonal antibody against the rat liver glucocorticoid receptor. Endocrinology 1985;117:1803-1812.

21 Shipman GF, Bloomfield CD, Gajl-Peczalska K, Munck AU, Smith KA: Glucocorticoids and lymphocytes. III. Effects of glucocorticoid administration on lymphocyte glucocorticoid receptors. Blood 1983;61:1086-1090.

22 Lippman M, Barr R: Glucocorticoid receptors in purified subpopulations of human peripheral blood lymphocytes. J Immunol 1977; 118:1977-1981.
23 Brentani MM, Wajchenberg BL, Cesar FP, Martins VR: Regulation of the glucocorticoid receptor by glucocorticoids in human mononuclear leucocytes. Horm Res 1986;24:9-17.

24 Schlechte JA, Ginsberg BH, Sherman BM: Regulation of the glucocorticoid receptor in human lymphocytes. J Steroid Biochem 1982;16:69-74.

25 Rupprecht R, Kornhuber J, Wodarz N, Göbel C, Lugauer J, Sinzger C, Beckmann H, Riederer P, Müller OA: Autoregulation of the glucocorticoid receptor in man: Up-regulation by metyrapone is avoided by dexamethasone pretreatment. J Neuroendocrinol 1990; 2:803-806.

26 Rupprecht R, Kornhuber J, Wodarz N, Lugauer J, Göbel C, Haack D, Müller OA, Riederer P, Beckmann H: Disturbed glucocorticoid receptor autoregulation and corticotropin response to dexamethasone in depressives pretreated with metyrapone. Biol Psychiatry, in press.

27 Hanifin JM. Rajka G: Diagnostic features of atopic dermatitis. Acta Derm Venereol Suppl (Stockh) 1980;92:44-47.

28 Costa C, Rilliet A. Nicolet M, Saurat JH: Scoring atopic dermatitis: The simpler the better? Acta Derm Venereol (Stockh) 1989;69: 41-45.

29 Boyum A: Separation of leukocytes from blood and bone marrow. Scand J Clin Lab Invest 1968:21:97-107.

30 Scatchard G: The attraction of proteins for small molecules and ions. Ann NY Acad Sci 1949;51:660-672.

31 Carroll BJ, Martin FI, Davis BM: Resistance to suppression by dexamethasone of plasma 11-OHCS levels in severe depressive illness. Br Med J 1968;iii:285-287.

32 McPershon GA: A practical computer-based approach to the analysis of radioligand binding experiments. Comput Programs Biomed 1983;17:107-114

33 Berger M, Pirke KM, Doerr P, Krieg JC. Zerssen D: The limited utility of the dexamethasone suppression test for the diagnostic process in psychiatry. Br J Psychiatry 1984;145:372-382.

34 Rupprecht R. Lesch KP: Psychoneuroendocrine research in depression. I. Hormone levels of different neuroendocrine axes and the dexamethasone suppression test. J Neural Transm 1989; 75:167-178.

35 Archer CB: Cyclic nucleotide metabolism in atopic dermatitis. Clin Exp Dermatol 1987;12:424-431

36 Saarinen UM: Transfer of latent atopy by bone marrow transplantation? J Clin Allergy Immunol 1984:74:196-200.

37 Tucker J, Barnetson R, Eden OB: Atopy after bone marrow transplantation. Br Med J 1985;290:116-117.

38 Saurat JH: Eczema in primary immune deficiencies. Clue to the pathogenesis of atopic dermatitis with special reference to the Wiskott-Aldrich syndrome. Acta Derm Venereol Suppl (Stockh) 1985; 114:125-128.

39 Dong Y, Aronsson JA, Okret S: The mechanism of cAMP-induced glucocorticoid receptor expression. J Biol Chem 1989;23: 13679-13683.

40 Damon M, Rabien M, Loubatière J, Blotman F, Crastes de Paulet A: Glucocorticoid receptors in fibroblasts from synovial tissue. Changes during the inflammatory process. Preliminary results. Agents Actions 1986;17:478-483.

41 Distelhost CW: Recent insight into the structure and function of the glucocorticoid receptor. J Lab Clin Med 1989;113:404-412.

42 Turner BB: Tissue differentiation in the up-regulation of glucocorticoid-binding proteins in the rat. Endocrinology 1986;118: 1211-1216 
43 Gustafsson J, Carlstedt-Duke J, Poellinger L, Okret S, Wikstöm A, Brönnegard M, Gillner M, Dong Y, Fuxe K, Cintra A, Härfstrand A, Agnati L: Biochemistry, molecular biology, and physiology of the glucocorticoid receptor. Endocr Reviews 1987;8:185-234.

44 Tsai BS, Watt G, Koensnadi K, Townley RG: Lymphocyte glucocorticoid receptors in asthmatic and control subjects. Clin Allergy 1984;14:363-371.

45 Griese M, Kusenbach G, Lüsebring K, Köster W, Roth B, Reinhardt D: Glucocorticoid receptors in mononuclear blood cells and their correlation to endogenous and exogenous corticoids in healthy and asthmatic children. Eur J Pediatr 1988;147: 490-495.

46 Rosewicz S, McDonald AR, Maddux BA, Goldfine ID, Miesfeld RL, Logsdon CD: Mechanism of glucocorticoid receptor downregulation by glucocorticoids. J Biol Chem 1988;263:2581-2584.
47 Antakly T, Raquidan D, O'Donnell O, Katnick L: Regulation of glucocorticoid receptor expression. I. Use of a specific radioimmunoassay and antiserum to a synthetic of the N-terminal domain. Endocrinology 1990;126:1821-1828.

48 Aas K: Common immunochemistry in atopic dermatitis and bronchial asthma. Acta Derm Venereol Suppl (Stockh) 1980;92:64-66.

Received: October 15, 1990

Accepted: January 18, 1991

Monika Rupprecht, MD

Department of Dermatology

Hartmannstrasse 14

D-W-8520 Erlangen (FRG) 